\title{
Peningkatan Daya Saing Produk Masker dengan Redesign dan Pengimplentasian Flexible Face Support di Kemuning Lor Arjasa Jember
}

\author{
Improvement of Mask Product Competitiveness with Redesign and Implementation of Flexible \\ Face Support on the Kemuning Lor Arjasa Jember
}

\author{
Feby Erawantini ${ }^{*}$, Azamataufiq Budi Prasojo ${ }^{2}$, Alex Taufiqurrohman Zain ${ }^{2}$ \\ ${ }^{1}$ Jurusan Kesehatan, Politeknik Negeri Jember \\ 2 Jurusan Teknik, Politeknik Negeri Jember \\ *feby_erawantini@polije.ac.id
}

\begin{abstract}
ABSTRAK
Sejak Maret 2020, World Health Organization telah menetapkan COVID-19 sebagai Pandemi. Penyebaran COVID-19 telah dikonfirmasi terjadi di seluruh Provinsi di Indonesia. Satu pasien yang dinyatan positif COVID-19 di Kabupaten Jember berasal dari Kecamatan Arjasa. Salah satu dari protokol berkomunikasi untuk mencegah penyebaran COVID-19 yaitu dengan menggunakan APD. Pada tanggal 5 April 2020 pemerintah mengumumkan bahwa semua orang hendak keluar rumah harus menggunakan masker. Menurut Referensi dari jurnal internasional disebutkan bahwa masker kain dapat menyaring $60 \%$ dari partikel. Masker kain yang banyak diproduksi saat ini masih hanya satu atau dua lapis saja. Tidak semua masker berbahan catton. Masker kain yang ada hanya berupa masker saja dan hanya melindungi saluran masuknya virus dari organ pernafasan. Sedangkan virus juga dapat menular dari mukosa mata dan telinga. Kebanyakan masyarakat menggunakan masker tanpa disertai pelindung mata dan telinga. Tujuan kegiatan pengabdian kepada masyarakat ini adalah Pemberdayaan masyarakat Desa Kemuning Lor Kecamatan Arjasa Jember untuk memproduksi Masker redesign Polije berbahan dasar catton batik khas Jember dilapisi dengan filter droplet, dapat melindungi mata dan telinga sehingga efektif untuk mencegah penyebaran COVID-19. Metode yang digunakan adalah Pendampingan, pelatihan dan ceramah. Kegiatan pengabdian kepada masyarakat dilaksankan pada bulan Juni sampai dengan Desember 2020. Hasil dari kegiatan ini yaitu peningkatan keterampilan masyarakat dalam membuat masker redesign Polije serta pemasaran maker secara online. Diharapkan kegiatan pengabdian masyarakat ini dapat menambah pendapatan masyarakat di era pandemi COVID-19.
\end{abstract}

Kata kunci - Masker, Redesign Polije, Desa Kemuning Lor, COVID-19

\begin{abstract}
Since March 2020, the World Health Organization has designated COVID-19 as a Pandemic. The spread of COVID-19 has been confirmed to occur in all Provinces in Indonesia. One patient who tested positive COVID-19 in Jember Regency from Arjasa District. One of the communication protocols to prevent the spread of COVID-19 is by using PPE. On April 5, 2020, the government announced that everyone going out of the house must wear a mask. According to references from international journals, it is stated that cloth masks can filter $60 \%$ of particles. The cloth masks that are produced today are still only one or two layers. Not all masks are made of catton. The cloth masks that exist are only in the form of masks and only protect the entry channels of viruses from the respiratory organs. While the virus can also be transmitted from the eye and ear mucosa. Most people use masks without eye and ear protection. The purpose of this community service activity was to empower the people of Kemuning Lor Village, Arjasa Jember Subdistrict to produce a Polije redesign mask made from the Jember ethnic of batik catton coated with a droplet filter, which Could protect the eyes and ears so that it was effective in preventing the spread of COVID-19. The methods ware used mentoring, training and lecturing. Community service activities were carried out from June to December 2020. The result of this activity was an increase in community skills in making Polije redesign masks and online marketing of makers. It is hoped that this community service activity can increase people's income in the era of the COVID-19 pandemic.
\end{abstract}

Keywords - Mask, Redesign Polije, Desa Kemuning Lor, COVID-19 


\section{Pendahuluan}

Coronavirus disease 19 atau disingkat COVID-19 adalah penyakit menular yang disebabkan oleh jenis coronavirus yang baru ditemukan di Wuhan, Tiongkok pada bulan Desember 2019[1]. Sejak Maret 2020, World Health Organization telah menetapkan COVID19 sebagai Pandemi. Penyebaran COVID-19 telah dikonfirmasi terjadi di seluruh provinsi di Indonesia dan jumlahnya selalu bertambah, menjadi sekitar 1000 kali dalam waktu satu bulan. Jumlah kematian karena COVID-19 di Indonesia sangat tinggi dibandingkan negaranegara lainnya [1].

Perkembangan kasus COVID-19 di Jawa Timur per tanggal 28 April 2020 melonjak secara signifikan. Jumlah total kasus positif 857 orang, tertinggi kedua setelah DKI Jakarta [2]. Jember merupakan salah satu kabupaten di Jawa Timur dengan kategori zona merah. Berdasarkan data pemantauan COVID-19 di Kabupaten Jember per tanggal 28 April 2020 bahwa jumlah kasus positif yaitu 11 orang [3]. Satu pasien yang dinyatakan positif COVID-19 di Kabupaten Jember berasal dari Kecamatan Arjasa. Salah satu Desa di Kecamatan Arjasa adalah Desa Kemuning Lor yang merupakan desa binaan Politeknik Negeri Jember. Agar COVID-19 tidak menyebar ke seluruh penduduk di Kecamatan Arjasa atau masyarakat Jember dan sekitarnya, maka perlu diterapkan protokol kesehatan penanganan COVID-19 yang telah diterbitkan pemerintah pada tanggal 6 Maret 2020 [4].

Salah satu dari protokol berkomunikasi untuk mencegah penyebaran COVID-19 yaitu dengan menggunakan masker dan alat pelindung diri (APD). Pada tanggal 5 April 2020 pemerintah mengumumkan bahwa semua orang hendak keluar rumah harus menggunakan masker. Masker bedah dan masker N95 hanya untuk petugas kesehatan, untuk masyarakat umum dapat menggunakan masker kain yang dapat di gunakan selama 4 jam setelah itu dapat dicuci dengan sabun[5].

Oleh karena kebijakan tersebut, maka tingkat kebutuhan akan masker kain bagi masyarakat terus meningkat. Kementerian koperasi (Kemkop) dan UKM mengajak para pelaku koperasi dan usaha mikro kecil dan menengah (UMKM) Indonesia terutama yang bergerak di bidang fashion dan konveksi agar membantu program pemerintah dalam gerakan masker kain dengan memproduksi lebih banyak masker berbahan baku kain [6].

Di Desa Kemuning Lor, terdapat UMKM yang bergerak di bidang konveksi dan penjahitan, yang juga turut terdampak adanya COVID-19 [7]. Hal ini dilihat dari adanya penurunan pesanan jahitan. Omset yang dimiliki sebelumnya berkisar Rp 250.000,00 per pekan, sekarang mengalami penurunan drastis yang bahkan bisa tidak mendapatkan pesanan dalam seharinya. Beberapa sudah berusaha memproduksi masker secara mandiri, namun ternyata masker tersebut masih terlalu sederhana.

Berdasarkan hasil diskusi dan komunikasi dengan Bapak Kepala Desa dan UMKM di Desa Kemuning Lor, warga masyarakat sangat antusias untuk mendapatkan cara meningkatkan omset yang turun selama adanya wabah ini. Masker yang akan dibuat berupa adanya redesign dengan menambahkan face support dan face shield. Biaya pembuatan masker per buah tidak lebih dari Rp 7.000,00, masker ini dapat dijual sekitar Rp 15.000,00 sehingga keuntungan setiap 100 buah yang terjual dapat mencapai $\mathrm{Rp}$ $800.000,00$. Warga masyarakat nantinya akan diberikan tutorial cara pemasaran masker-shield secara online.

\section{Target dan Luaran}

Target dan luaran pada kegiatan pengabdian masyarakat ini yaitu publikasi pada jurnal J-Dinamika adanya teknologi tepat guna berupa masker redesign polije berbahan katun yaitu batik khas Jember dilapisi dengan filter droplet, dapat melindungi mata dan telinga sehingga efektif untuk mencegah penyebaran COVID-19, pemasaran online dengan ecommerce dan publikasi kegiatan melalui media masa Jember pos.

\section{Metodologi}

Metode Pengabdian masyarakat
digambarkan sebagai berikut:




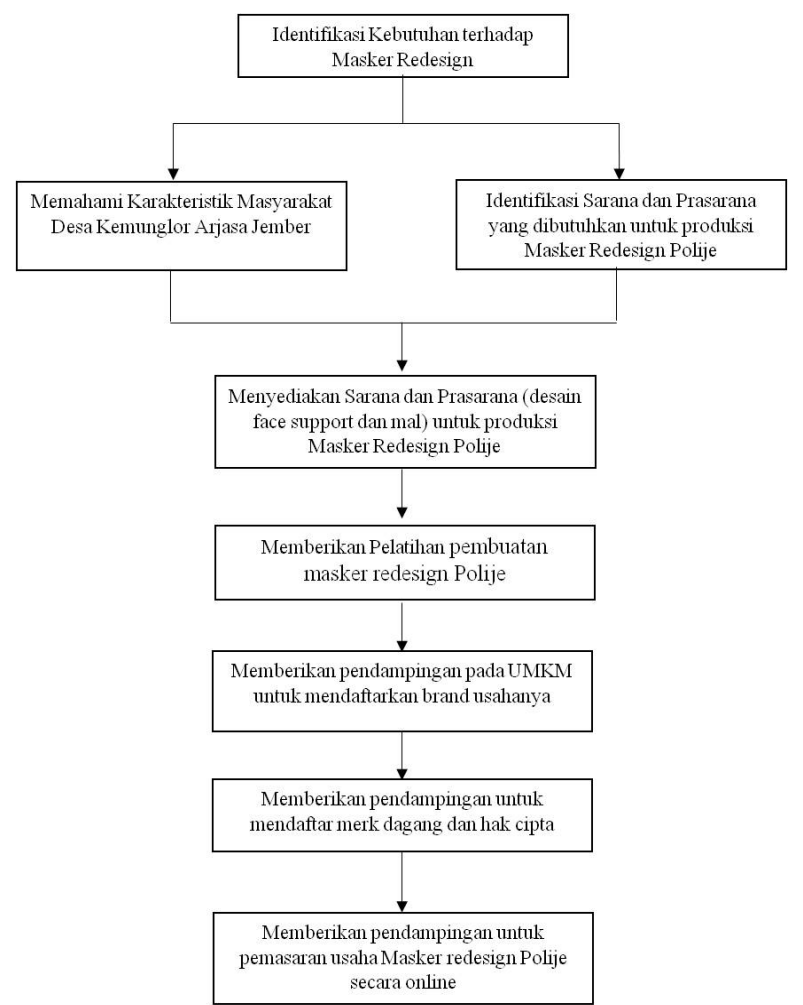

Gambar 1. langkah-langkah menyelesaikan masalah mitra

Langkah pertama yang harus dilakukan oleh Tim Pengabdian Masyarakat Politeknik Negeri Jember adalah Identifikasi kebutuhan masyarakat terhadap APD dalam hal ini Masker redesign Polije. Selanjutnya adalah memahami karakteristik masyarakat Desa Kemuning Lor Arjasa Jember yang guyub rukun serta pekerja keras, dan sebagian besar adalah generasi muda. kemudian Identifikasi dan menyediakan sarana dan prasarana yang dibutuhkan untuk produksi Masker redesign Polije, bahan utama berupa face support dari resin, plastik mika dan kain katun batik asli Jember. Sarana dan prasarana sangat penting untuk produksi Masker redesign Polije. Tahap selanjutnya adalah memberikan pelatihan kepada UMKM cara membuat Masker redesign Polije, meliputi mendesain pola secara manual atau juga dapat menggunakan aplikasi CAD, serta menjahit Masker redesign. selanjutnya adalah memberikan pendampingan pada UMKM untuk mendaftarkan brand usahanya. Tahap akhir adalah Memberikan pendampingan untuk pemasaran usaha Masker redesign Polije secara online. Sehingga Masker redesign Polije tidak hanya dapat digunakan oleh masyarakat Kemuning Lor atau Jember namun dapat dipasarkan ke seluruh pelosok tanah air. Kegiatan dilaksanakan bulan Juni sampai dengan Desember 2020.

\section{Pembahasan}

\subsection{Masyarakat Desa Kemuning Lor Arjasa Jember}

Masyarakat Desa Kemuning Lor Arjasa Jember sebagian besar adalah etnis Madura. Kehidupan sehari-hari mereka yaitu bertani, budidaya tanaman perkebunan seperti kopi, buah naga serta tanaman hias. UMKM yang ada di Desa Kemuning Lor diantaranya yaitu UMKM Susu dan industri konveksi. Industri konveksi diketuai oleh Ibu Satiyah. Anggota UMKM konveksi berjumlah 10 orang. Jarak rumah Ibu Satiyah dan Anggota saling berdekatan atau bertetangga. Tim Pengabdian Masyarakat Politeknik Negeri Jember berkoordinasi dengan Kepala desa dan Ketua UMKM konveksi untuk

\subsection{Pelatihan pembuatan masker shield}

UMKM Desa Kemuning Lor diberi pelatihan oleh Team Pengabdian Masyarakat Politeknik Negeri Jember cara mendesain Masker redesign Polije. Desain face support dapat dilakukan secara manual dengan kertas karton atau desain 3D dengan aplikasi CAD. Selanjutnya, desain dicetak untuk menjadi model cetakan face support berbahan dasar resin.

Berikut kegiatan pelatihan pembuatan masker shield di Desa Kemuning Lor:

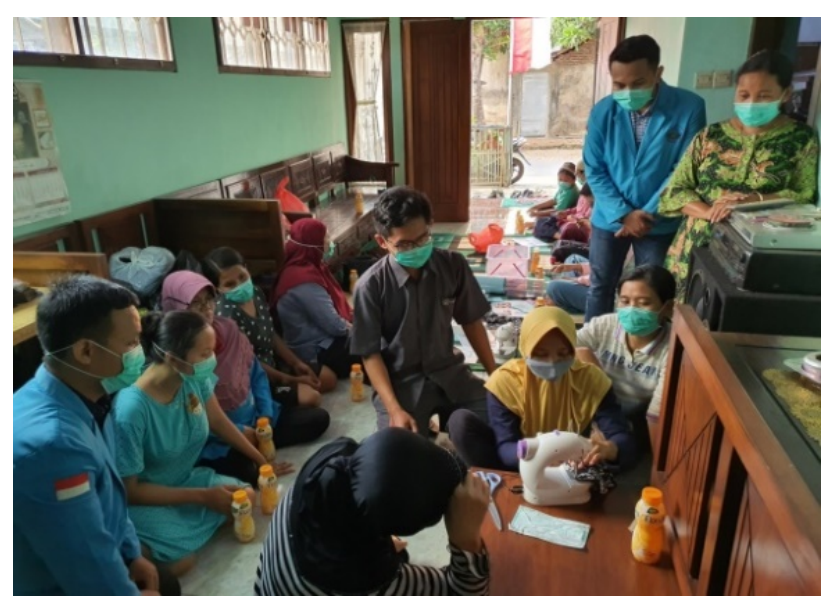

Gambar 2. Pelatihan Pembuatan Masker bersama Masyarakat Desa Kemuning Lor 


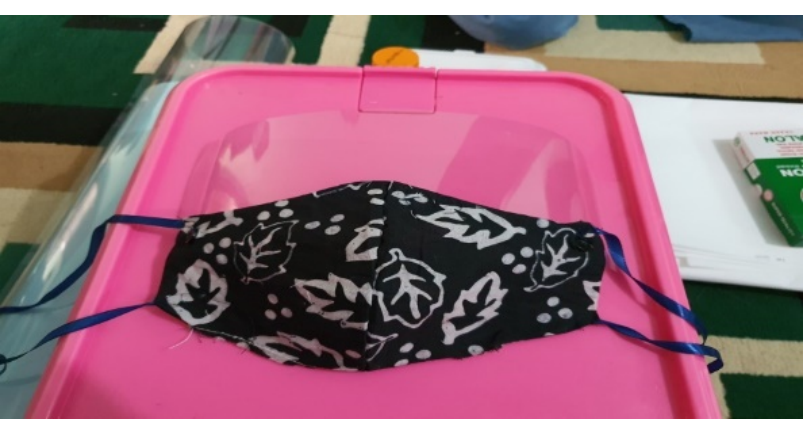

Gambar 3. Masker Redesign Polije

Prinsip pembuatan masker redesign Polije adalah produk ini benar-benar berfungsi efektif untuk pencegahan COVID-19. Face support digunakan pada masker yang terdiri dari 3 lapis kain. Bagian tengah dari masker adalah kain pelapis sehingga tidak dapat mengeluarkan gas keluar masker. Pembuatan masker redesign Polije menggunakan prinsip Ergonomi sehingga benar-benar sesuai dengan antropometri wajah penggunanya dan benar-benar nyaman digunakan, hal ini sesuai dengan kemampuan ketua team dari Jurusan kesehatan sebagai Dosen Pengampu Mata Kuliah Ergonomi, Kesehatan dan Keselamatan Kerja di Program Studi Rekam Medis Jurusan Kesehatan Politeknik Negeri Jember[8].

\section{Kesimpulan}

Tim Pengabdian Masyarakat Politeknik Negeri Jember, telah berkoordinasi dengan Kepala Desa Kemuning Lor an UMKM Konveksi dan memberikan motivasi kepada UMKM untuk berpartisipasi dalam mencegah COVID-19 dengan memproduksi masker shield. pelatihan pembuatan masker shield telah dilakukan. Pendampingan UMKM akan terus dilakukan sampai dengan Desember 2020.

Luaran yang telah tercapai yaitu desain produk industri, teknologi tepat guna, draf hak cipta, draf buku dan draf publikasi media masa.

\section{Ucapan Terima Kasih}

Ucapan terima kasih tim penulis sampaikan kepada Politeknik Negeri Jember yang telah memberikan dukungan penuh pada kegiatan pengabdian masyarakat ini.

\section{Daftar Pustaka}

[1] WHO, "Pertanyaan dan Jawaban Terkait Coronavirus," World Health Organization, 2020. https:/www.who.int/indonesia/news/novelcoronavirus/qa-for-public.[2] R. K. Hastuti, "Kasus Positif Corona di Jatim Melonjak Signifikan, Ada Apa?," $\quad C N B C \quad$ Indonesia, 2018. https://www.cnbcindonesia.com/news/20200428182 504-4-155063/kasus-positif-corona-di-jatimmelonjak-signifikan-ada-apa.

[3] PEMKAB JEMBER, "No Title," Jember, 2018. [Online]. Available: http://www.jemberkab.go.id/data-covid-19/.

[4] Pemerintah, "Pemerintah Terbitkan Protokol Kesehatan Penanganan COVID-19," Kantor Staf Presidenan, 2020. http://ksp.go.id/pemerintahterbitkan-protokol-kesehatan-penanganan-covid19/index.html.

[5] A. Budiansyah, "Catat, Wajib Pakai Masker Buat Semua Warga RI Mulai Hari Ini!," CNBC Indonesia, 2020.

https://www.cnbcindonesia.com/lifestyle/202004051 74659-33-149879/catat-wajib-pakai-masker-buatsemua-warga-ri-mulai-hari-ini.

[6] Teten Masduki, "Kemkop dan UKM Ajak KUMKM Indonesia Produksi Masker Kain,” Berita Satu, 2020. https:/www.beritasatu.com/ekonomi/618471kemkop-dan-ukm-ajak-kumkm-indonesia-produksimasker-kain

[7] A. G. U. Desa, T. Tegalan, and T. Wisata, "Profil Desa Kemuninglor," in 1, Jember, 2020.

[8] J. Kesehatan, "Kesehatan dan Keselamatan Kerja," Politeknik Negeri Jember, 2020. 